\title{
MAREK PYC \\ Czy rzeczywiście encyklika Spe salvi przekreśla nadzieję na uniwersalne zbawienie? Krytyczne uwagi odnośnie do jej polskiego tlumaczenia
}

„W nadziei już jesteśmy zbawieni” (Rz 8, 24). Te wlaśnie slowa z Listu św. Pawla do Rzymian obrał Benedykt XVI za motto encykliki o chrześcijańskiej nadziei Spe salvi (SS 1). Trafily one jednak na trudny grunt w polskim wydaniu watykańskiego „L'Osservatore Romano"”. Już pierwsze zdanie komentarza wprowadzajacego w lekturę papieskiego dokumentu wprawia w zdumienie. Czytamy tam: Wiara, nadzieja i milość to cnoty, ktore Kościól nazywa teologalnymi bqqdź teologicznymi, choć nie majq one większego zwiqzku z teologiqa. Trudno zrozumieć, co anonimowy autor tego tekstu mial na myśli i jakim sposobem tak niefortunnie sformulowana teza znalazla się na lamach tej rangi periodyku.

Znacznie większe wątpliwości rodzą się jednak w trakcie lektury polskiego thumaczenia encykliki. Trzecia jej część, zatytułowana: Sąd Ostateczny jako miejsce uczenia się nadziei i wprawiania się w niej, poświęcona jest w znacznej mierze refleksji na temat piekla, nieba i czyśćca (SS 45-48). Znajdujemy tam fragment mówiący o fundamentalnej decyzji czlowieka, która w ciagu calego życia nabiera ksztaltu i w ostateczności może mieć różnoraki charakter. W polskim wydaniu „L'Osservatore Romano" czytamy:

„Są ludzie, którzy całkowicie zniszczyli w sobie pragnienie prawdy i gotowość do kochania. Ludzie, w których wszystko stało się kłamstwem; ludzie, którzy żyli w nienawiści i podeptali w sobie miłość. Jest to straszna perspektywa, ale w niektórych postaciach naszej historii można odnaleźć w

\footnotetext{
${ }^{1}$ Por. „L'Osservatore Romano”. Wydanie polskie. R. 29: 2008 nr 1 s. 3-24.

${ }^{2}$ Tamże, s. 3.
} 
sposób przerażający postawy tego rodzaju. Takich ludzi już nie można uleczyć, a zniszczenie dobra jest nieodwołalne: to jest to, na co wskazuje słowo pieklo" (SS 45).

Odnoszący się do piekła fragment encykliki dotyka kluczowej w teologii prawdy o zbawieniu. Wskutek niezbyt precyzyjnego polskiego thumaczenia pojawił się jednak problem. Wybitny polski ekumenista, Waclaw Hryniewicz, publikując w grudniu 2007 r. w „Gazecie Wyborczej” artykul pt. Nadzieja czy strach?, zacytowal przytoczony wyżej tekst. Sformulowal przy tym zarzut:

„Jak większość Kościołów, również mój, rzymskokatolicki, dystansuje się od nadziei powszechnego zbawienia. Benedykt XVI wyraźnie nawiązuje w swojej encyklice »W nadziei zbawieni « do Katechizmu Kościoła Katolickiego, do tradycyjnej nauki o istnieniu piekła i jego wieczności”.

Pomijając już fakt, czy „Gazeta Wyborcza” jest odpowiednim forum dla tak poważnej i zlożonej teologicznej dysputy, wypada postawić w tym miejscu pytanie: Czy rzeczywiście encyklika Spe salvi przekreśla nadzieję na uniwersalne zbawienie? Pytanie to okazuje się tym bardziej zasadne, gdy weźmie się pod uwagę orientację teologiczną i wieloletni dorobek naukowy Josepha Ratzingera, profesora uniwersyteckiego, a następnie prefekta Kongregacji Nauki Wiary. Warto w tym miejscu nadmienić, że zagadnieniom eschatologicznym poświęcil on wiele uwagi, a jedna z najbardziej znaczących w jego dorobku pozycji jest, opublikowana w 9-tomowej serii Kleine Katholische Dogmatik, książka pt. Eschatologie. Tod und ewiges Leben, Regensburg 1978 (thum. polskie: „Eschatologia-smierć i życie wieczne”, Poznań 1984).

Wracając do zacytowanego wyżej fragmentu polskiego thumaczenia encykliki należy zauważyć, że użycie w nim trybu oznajmującego (, sq ludzie”) jest w istocie równoznaczne ze stwierdzeniem faktu istnienia ludzi, którzy już zostali potępieni. Sa to ci, którzy „całkowicie zniszczyli w sobie pragnienie prawdy i gotowość do kochania”, „w których wszystko stało się klamstwem”, „którzy żyli w nienawiści i podeptali w sobie milość" i których, ,już nie można uleczyć, a zniszczenie dobra jest nieodwolalne". Jest tu mowa o ludziach definitywnie i nieodwolalnie zatraconych już w piekle. Sformulowanie takiego poglądu nie współgra jednak $z$ wielowiekowym nauczaniem Kościola. Teza o zaludnionym już piekle podważa żywioną od wieków - choć często przy bardzo burzliwych kontrowersjach - i obecną w modlitwie Kościoła nadzieję na uniwersalne zba-

\footnotetext{
${ }^{3}$ Tamże, s. 22. Identyczna wersja tego tekstu dostępna jest na watykańskiej stronie internetowej (www.vatican.va). Na stronie tej znajdują się także thumaczenia encykliki na inne języki cytowane w naszym opracowaniu.
} 
wienie. Stwierdzenie faktu istnienia potępionych stanowi niezwykle śmiała próbę ogarnięcia ludzką wiedzą nie objawionych nam, a tym samym niedostępnych naszemu poznaniu Bożych tajemnic. Nikt i nic nie uprawnia nas do wyrokowania o sprawach, które, jak się wyraził Jan Pawel II, pozostają niezgłębiona tajemnica pomiędzy świętościq Boga a ludzkim sumieniem ${ }^{4}$. Pojawiająca się w polskim thumaczeniu teza wydaje się być calkowicie obca zarówno papieskiemu nauczaniu, jak i wcześniejszej teologicznej twórczości J. Ratzingera.

W próbie odpowiedzi na nurtujace nas pytanie konieczna jest konfrontacja polskiego przekladu encykliki z jej lacińska oryginalną wersja, opublikowana w oficjalnym periodyku Stolicy Apostolskiej „Acta Apostolicae Sedis”. Zanim jednak odwolamy się do tekstu lacińskiego Spe salvi, warto sięgnąc do tlumaczeń encykliki na języki nowożytne, dając pierwszeństwo przekładowi na język niemiecki, który, jak można przypuszczać, będąc językiem ojczystym J. Ratzingera, mógł stanowić podstawę do stworzenia lacińskiej wersji omawianego dokumentu. Interesujacy nas fragment, opublikowany na internetowych stronach watykańskich, brzmi następujaco:

„Es kann Menschen geben, die in sich den Willen zur Wahrheit und die Bereitschaft zur Liebe völlig zerstört haben. Menschen, in denen alles Lüge geworden ist; Menschen, die dem Haß gelebt und die Liebe in sich zertreten haben. Dies ist ein furchtbarer Gedanke, aber manche Gestalten gerade unserer Geschichte lassen in erschreckender Weise solche Profile erkennen. Nichts mehr wäre zu heilen an solchen Menschen, die Zerstörung des Guten unwiderruflich: Das ist es, was mit dem Wort Hölle bezeichnet wird“ (SS 45).

W odróżnieniu od polskiego tekstu, gdzie jest mowa o zaistnialym już fakcie, a więc o faktycznym potępieniu przynajmniej niektórych (, sq ludzie”), tekst niemiecki wskazuje na możliwość istnienia potępionych (,es kann Menschen geben"). Dla podkreślenia, iż nie chodzi tu o fakt już dokonany, lecz o zagrażająca grzesznikom możliwość, w ostatnim zdaniu zacytowanego niemieckiego tekstu użyty zostaje tryb przypuszczający (,,nichts mehr wäre zu heilen an solchen

${ }^{4}$ J a n P a we $\nmid$ II: Przekroczyć próg nadziei. Lublin 2005 s. 147. W katechezie wygłoszonej podczas audiencji generalnej 28 lipca $1999 \mathrm{r}$. J a n P a w e 1 I I powiedzial: La dannazione rimane una reale possibilità, ma non ci è dato di conoscere, senza speciale rivelazione divina, se e quali esseri umani vi siano effettivamente coinvolti. Il pensiero dell'inferno - tanto meno l'utilizzazione impropria delle immagini bibliche - non deve creare psicosi o angoscia, ma rappresenta un necessario e salutare monito alla libertà, all'interno dell'annuncio che Gesù Risorto ha vinto Satana, donandoci lo Spirito di Dio, che ci fa invocare "Abbà, Padre« (Rm 8, 15; Gal 4, 6). Questa prospettiva ricca di speranza prevale nell'annuncio cristiano. Essa viene efficacemente riflessa nella tradizione liturgica della Chiesa.

${ }^{5}$ Acta Apostolicae Sedis. Commentarium Officiale. R. 99: 2007 nr 12 s. 985-1027. Publikowane w AAS teksty stanowią wersję oryginalną najważniejszych dokumentów Kościola. 
Menschen"), podczas gdy w tekście polskim przy zastosowaniu trybu oznajmujacego ponownie stwierdza się fakt (,, takich ludzi już nie można uleczyć, a zniszczenie dobra jest nieodwolalne").

Opublikowane na stronach internetowych Stolicy Apostolskiej thumaczenia na inne języki nowożytne w pelni harmonizują z przekładem niemieckim:

\section{Wersja wloska:}

„Possono esserci persone che hanno distrutto totalmente in se stesse il desiderio della verità e la disponibilità all'amore. Persone in cui tutto è diventato menzogna; persone che hanno vissuto per l'odio e hanno calpestato in se stesse l'amore. E questa una prospettiva terribile, ma alcune figure della stessa nostra storia lasciano discernere in modo spaventoso profili di tal genere. In simili individui non ci sarebbe più niente di rimediabile e la distruzione del bene sarebbe irrevocabile: è questo che si indica con la parola inferno" (SS 45).

\section{Wersja francuska:}

„Il peut y avoir des personnes qui ont détruit totalement en elles le désir de la vérité et la disponibilité à l'amour. Des personnes en qui tout est devenu mensonge; des personnes qui ont vécu pour la haine et qui en elles-mêmes ont piétiné l'amour. C'est une perspective terrible, mais certains personnages de notre histoire laissent entrevoir de façon effroyable des profils de ce genre. Dans de semblables individus, il n'y aurait plus rien de remédiable et la destruction du bien serait irrévocable: c'est cela qu'on indique par le mot »enfer «" (SS 45).

Wersja hiszpańska:

„Puede haber personas que han destruido totalmente en sí mismas el deseo de la verdad y la disponibilidad para el amor. Personas en las que todo se ha convertido en mentira; personas que han vivido para el odio y que han pisoteado en ellas mismas el amor. Ésta es una perspectiva terrible, pero en algunos casos de nuestra propia historia podemos distinguir con horror figuras de este tipo. En semejantes individuos no habría ya nada remediable y la destrucción del bien sería irrevocable: esto es lo que se indica con la palabra infierno" (SS 45).

Wersja angielska:

„There can be people who have totally destroyed their desire for truth and readiness to love, people for whom everything has become a lie, people who 
have lived for hatred and have suppressed all love within themselves. This is a terrifying thought, but alarming profiles of this type can be seen in certain figures of our own history. In such people all would be beyond remedy and the destruction of good would be irrevocable: this is what we mean by the word Hell" (SS 45).

Nade wszystko jednak konieczne jest odwolanie się do oryginalnej lacińskiej wersji interesujacego nas fragmentu:

\begin{abstract}
„Sunt quidam qui veritatis desiderium amorisque alacritatem deleverint. In iis omnia facta sunt mendacia; ii odio vixerunt iique in se amorem ipsi proculcarunt. Terrificus est hic prospectus, sed quaedam nostrae historiae personae huius generis species horrendum in modum agnoscere sinunt. Talibus in hominibus nihil sanabile invenias et boni dissipatio irreparabilis: id ipsum inferni verbo significatur" (SS 45$)^{6}$.
\end{abstract}

Analizując ten tekst, należy zwrócić uwagę na użyty w pierwszym zdaniu coniunctivus ,deleverint". Jakkolwiek jego użycia wymaga już sama składnia, wprowadza on jednak w to zdanie specyficzny klimat. Coniunctivus ,deleverint" pozwala na przethumaczenie tego fragmentu w sensie: „można by bylo o nich sądzić, że zniszczyli...". Jest tu wyrażone pewne subiektywne przekonanie, myśl „ex mente auctoris”, albo też możliwość: „którzy mogliby zniszczyć...”. Łaciński tekst nie pozwala na stwierdzenie w prosty sposób faktu istnienia potępionych i nie podejmuje próby opisu faktycznej, zaistnialej już rzeczywistości. Zostaje w nim wyrażona raczej opinia, bąź też subiektywne przekonanie, które mogloby nasuwać się formulującemu taki pogląd w kontekście dramatycznych dziejów świata. Nadto w tekście lacińskim nie pojawia się słowo „calkowicie”, użyte przez polskiego thumacza $\mathrm{w}$ pierwszym zdaniu (obecne jednak $\mathrm{w}$ thumaczeniach na języki nowożytne). To, że nie ma w cytowanym tekście mowy o faktycznie zaistniałej już rzeczywistości, lecz o stojacej przed ludźmi przerażajacej możliwości potępienia, potwierdza końcowe zdanie omawianego fragmentu: Talibus in hominibus nihil sanabile invenias et boni dissipatio irreparabilis. W szczególności chodzi o użyty w trybie przypuszczającym czasownik »invenias«, co i tu sugerowaloby możliwość potępienia (takich ludzi nie można by już uleczyć, a zniszczenie dobra okazaloby się $w$ nich nieodwolalne), a nie proste stwierdzenie definitywnie już zaistniałego faktu (takich ludzi już nie można uleczyć, a zniszczenie dobra jest nieodwolalne). Takie rozumowanie potwierdza dodatkowo dalsza część tekstu dotycząca nieba, gdzie czytamy, iż, w przeciwieństwie do możliwości potępienia, istnieje, z drugiej strony, możliwość bezpośredniego osiagnięcia nieba przez ludzi calkowicie czystych:

\footnotetext{
${ }^{6}$ Tamże, s. 1022
} 
„At contra integerrimae personae esse possunt, quae se a Deo penitus pervadi sunt passae, quapropter omnino proximo praesto sunt. De hominibus nempe agitur, qui a Deo communicato toti prorsus diriguntur, quorum ad Deum accessio illud solummodo complet quod ii iam sunt" (SS 45) ${ }^{7}$.

Także i w tym wypadku thumaczenie polskie, w odróżnieniu od wersji lacińskiej, nie mówi o możliwości, lecz stwierdza zaistniały fakt:

„Z drugiej strony, są ludzie całkowicie czyści, którzy pozwolili się Bogu wewnętrznie przeniknąć, a w konsekwencji są całkowicie otwarci na bliźniego ludzie, których całe istnienie już teraz kształtuje komunia z Bogiem i których droga ku Bogu prowadzi jedynie do spełnienia tego, czym już są" (SS 45).

Wydaje się zatem, że omawiany fragment encykliki należałoby przethumaczyć w następujący sposób: „Mogą być tacy ludzie, którzy zniszczyli w sobie pragnienie prawdy i goto-
wość do kochania; ludzie, w których wszystko stało się kłamstwem; ludzie,
którzy żyli w nienawiści i podeptali w sobie miłość. Jest to straszna perspekty-
wa, ale w niektórych postaciach naszej historii można odnaleźć w sposób prze-
rażający postawy tego rodzaju. Takich ludzi nie można by już uleczyć, a
zniszczenie dobra okazałoby się nieodwołalne: to jest to, na co wskazuje sło-
wo piekło” (SS 45).

Warto uświadomić sobie, że nie chodzi tu o zwyklą szkolna, teoretyczną debatę nad dokonanym thumaczeniem, mająca na celu wykazanie zaistnialych nieścisłości. Dotykamy bowiem kwestii ludzkiego zbawienia, przynależącej do samego rdzenia wyznawanej i przeżywanej przez nas wiary. Polskie thumaczenie omawianego fragmentu encykliki Benedykta XVI zdaje się bazować na »wiedzy « o rzeczach, które, zgodnie z wolą Boga, pozostają dla nas zakryte. Uderza ono w naszą wiarę w Boga, Sędziego, ale i zarazem Zbawiciela, w Jego odwieczny zamysł i pragnienie, by wszyscy dostapili zbawienia, a tym samym podważa nasza nadzieję na powszechne zbawienie. Nasyconej ufnościa chrześcijańskiej nadziei nie wolno pod żadnym pozorem pomylić z plynącą $\mathrm{z}$ wiedzy pewnością. Podobnie jak odrzucona została przez Kościół teoria apokatastazy ostatecznej, glosząca pewność zbawienia wszystkich i odnowienia całej rzeczywistości na końcu czasów, na równi niedopuszczalne jest wyrokowanie o potępieniu, które stało się już faktem, i gloszenie tezy o zaludnionym na wieczność piekle.

Zaprezentowaną wyżej interpretację tekstu encykliki potwierdza wcześniejsze nauczanie J. Ratzingera jako teologa, a później prefekta Kongregacji Nauki

${ }^{7}$ Tamże. 
Wiary. Jednoznacznie mówi on o piekle i możliwości potępienia zagrażającego grzesznikom. Będąc wolnym, czlowiek może sprzeciwić się boskim zamiarom. Bóg respektuje jego wolność. Nie traktuje go jako istoty niezdolnej do dźwignięcia odpowiedzialności za swój los. Nikt nie zostanie zbawiony wbrew wlasnej woli, gdyż niebo można osiagnać jedynie na zasadzie wolności. Człowiek powinien być jednak świadomy, że jego bezbożne życie może prowadzić do wiecznej zatraty $^{8}$. Otchłań, którą nazywamy piekłem, otwiera sobie on sam, odrzucając milość Boga i chcąc pozostać calkowicie samowystarczalnym. Piekłem jest doprowadzona do ostatecznych granic samotność, spowodowana absurdalnym dążeniem do niezależności i usilowaniem, by być jak Bóg, gardząc oferowanym darem milości ${ }^{9}$. Gdyby istniała taka samotność, do której nie moglaby przedostać się milość, a więc której nie byloby w stanie dosięgnać słowo miłości, mielibyśmy do czynienia $z$ piekłem ${ }^{10}$. Joseph Ratzinger dostrzega jednak nadzieję $w$ Jezusie Chrystusie, który sam wkracza w wolność grzeszacych swoją większą od niej wolnością. Jego milość sięga samego dna otchlani. Tajemnica tego, co się tu dokonuje, choć spowita mrokiem zstapienia Jezusa do piekiel, którego czlowiek nie jest w stanie przeniknać, niesie nadzieję na ostateczny triumf zbawczej miłości $^{11}$.

Czy zatem wolno postawić Benedyktowi XVI zarzut, że w encyklice Spe salvi przekreśla nadzieję na uniwersalne zbawienie? Taka myśl moglaby się zrodzić po lekturze niezbyt precyzyjnego polskiego thumaczenia papieskiego dokumentu. Nie sposób jednak wyciagnąc takiego wniosku po konfrontacji polskiej wersji z tekstem oryginalnym. W encyklice Spe salvi Papież odczytuje tradycję Kościola w tak bardzo potrzebnym dziś Kościolowi i światu klimacie nadziei. Polskie thumaczenie nie harmonizuje $z$ calościa, przenikniętej nadzieją, myśli papieskiej. Pojawiaja się w nim sformulowania nie mieszczące się w granicach katolickiej ortodoksji, a tym samym wprowadzajace w bląd i pozbawiajace $\mathrm{w}$ efekcie nadziei tych, którzy w dobrej wierze, z szacunkiem dla kościelnego autorytetu sięgaja po ten tekst.

\footnotetext{
${ }^{8}$ Por. J. R a tz ing e r: Eschatologia - śmierć i życie wieczne. Poznań 1984 s. 236-237.

${ }^{9}$ Por. J. R a t z in g e r: Wprowadzenie w chrześcijaństwo. Kraków 1970 s. 249 i 258-259.

${ }^{10}$ Por. tamże, s. 247.

${ }^{11}$ Por. J. R a $\mathrm{z}$ i n g e r: Eschatologia-śmierć $i$ życie wieczne, dz. cyt., s. 237.
} 